\title{
Young men who do not drink, as well as those who drink heavily, have high levels of depression and distress
}

\author{
Caldwell TM, Rodgers B, Jorm AF et al. Patterns of association between alcohol consumption and symptoms of depression
} and anxiety in young adults. Addiction 2002 May;97:583-594.

\section{QUESTION: Do non-drinkers and hazardous/harmful drinkers have increased symptoms of depression and anxiety during young adulthood?}

\section{Design}

Cross sectional analysis of population-based cohort study.

\section{Setting}

Canberra region, Australia; March 1999 to February 2000.

\section{Participants}

Random sample of 2404 people aged between 20 and 24 years participating in the 'Path Through Life' project, an ongoing study with interviews every 4 years for 20 years. Complete data were available for 95\% (2276).

\section{Assessment of risk factors}

The Goldberg Depression and Anxiety Scales, Positive and Negative Affect Schedule and Alcohol Use Disorders Identification Test were completed using hand-held computers.

\section{Main outcome measures}

Alcohol consumption; anxiety; depression; positive and negative affect.

\section{Main results}

For men, both hazardous/harmful and non/occasional drinkers reported higher symptom scores and lower positive affect than light drinkers. The mental health of non-drinkers could not be explained by a history of hazardous/harmful drinking or current tobacco or cannabis use. Higher levels of distress were accounted for by poorer physical health and lower extraversion. For women, hazardous/harmful drinkers had higher levels of depression and negative affect. Recent stressful events and cannabis and tobacco consumption were important for understanding levels of distress among male and female hazardous/harmful drinkers.

\section{Conclusions}

Heavy drinkers and male non-drinkers reported increased distress, but had little else in common. These findings contradict hypotheses that account for nondrinkers' distress with past problem drinking, other substance use or characteristics common to heavy drinkers.

Sources of funding: The National Health and Medical Research Council; Australian

Rotary Health

Research Fund; Australian Brewers Foundation.

For correspondence: Tanya Caldwell, Centre for Mental Health Research, Australian

National University, Australia. tanya.caldwell@ anu.edu.au

\section{Mean Goldberg and PANAS scores by alcohol consumption}

\begin{tabular}{lccccccccc} 
& \multicolumn{2}{c}{$\begin{array}{c}\text { Non/occasional } \\
\text { drinkers }\end{array}$} & \multicolumn{2}{c}{$\begin{array}{c}\text { Light } \\
\text { drinkers }\end{array}$} & \multicolumn{2}{c}{$\begin{array}{c}\text { Moderate } \\
\text { drinkers }\end{array}$} & \multicolumn{2}{c}{$\begin{array}{c}\text { Hazardous / } \\
\text { harmful drinkers }\end{array}$} \\
\cline { 2 - 10 } $\begin{array}{c}\text { Unadjusted } \\
\text { variable }\end{array}$ & $\begin{array}{c}\text { Men } \\
(n=294)\end{array}$ & $\begin{array}{c}\text { Women } \\
(n=426)\end{array}$ & $\begin{array}{c}\text { Men } \\
(n=606)\end{array}$ & $\begin{array}{c}\text { Women } \\
(n=551)\end{array}$ & $\begin{array}{c}\text { Men } \\
(n=126)\end{array}$ & $\begin{array}{c}\text { Women } \\
(n=122)\end{array}$ & $\begin{array}{c}\text { Men } \\
(n=70)\end{array}$ & $\begin{array}{c}\text { Women } \\
(n=81)\end{array}$ \\
Depression & 2.8 & 3.2 & 2.3 & 3.0 & 2.5 & 3.3 & 3.6 & 3.8 \\
\hline Anxiety & 3.4 & 4.4 & 3.0 & 4.4 & 3.2 & 4.5 & 4.2 & 4.9 \\
\hline $\begin{array}{c}\text { Positive } \\
\text { affect }\end{array}$ & 32.8 & 32.0 & 34.1 & 32.9 & 33.4 & 32.9 & 31.9 & 32.3 \\
\hline
\end{tabular}

Note: all scores for non-drinking and 'harmful drinking' men were significantly different from light drinkers ( $p<$ 0.05). Only depression scores for female 'hazardous / harmful' drinkers reached statistical significance.

\section{COMMENTARY}

A number of studies have investigated the links between alcohol consumption and mental health problems, although few have specifically targeted young adults. Substance use and alcohol consumption is increasing among young people in Western countries. ${ }^{1}$ Community-based surveys suggest that alcohol disorders often coexist with anxiety and depression. This study uses a large community sample, although some of the conclusions are debatable. The authors suggest that a higher level of distress among male non-drinkers may be due to violation of social norms, but no information was collected about peer pressure or peer acceptance. Differences in mean depression and anxiety scores between the non/occasional and light drinking groups might result from the confounding effects of extroversion, physical health and employment status.

The authors suggest that high levels of distress in male non/occasional and harmful drinkers might be evidence that distress polarizes drinking behavior. This conclusion is premature for a cross-sectional study. Using a national representative sample, my colleague and I investigated the impact of major depressive episodes on alcohol consumption. ${ }^{2}$ We found no evidence that depression affected the initiation, frequency or amount of alcohol consumed among men, but major depressive episodes increased the risk of harmful drinking among women.

'Social selection' and 'social causation' models predict an inverse relationship between socioeconomic status and various types of psychopathology, including depression and alcohol-related disorders. ${ }^{3}$ In this study, demographic and socioeconomic variables such as race, immigration status and income were not fully described, although it is likely that data were collected.

Mean depression and anxiety scores were compared for different levels of alcohol consumption, but the distributions of depression and anxiety scores are often skewed which precludes a direct comparison of means. Direct comparisons of mean scores are not appropriate unless the scores were normally distributed. In another study involving 5 of the same authors, the distributions of depression and anxiety scores were skewed so data transformation and population norms were used. ${ }^{4}$ It is surprising that a similar approach was not used here.

Selection bias is also possible. Although the final sample was large ( $\mathrm{n}=2276)$, only about $55 \%$ of those contacted and eligible for the study ( $\mathrm{n}=4105)$ provided complete information.

JianLi Wang, PhD Assistant Professor Departments of Psychiatry and Community Health Sciences, Faculty of Medicine, University of Calgary, Canada

1 Pouline C, Elliott D. Alcohol, tobacco and cannabis use among Nova Scotia adolescents: implications for prevention and harm reduction. Canadian Medical Association Journal 1997; 156: 1387-93.

Wang J, Patten SB. A prospective study of sex specific effects of major depression on alcohol consumption. Canadian Journal of Psychiatry 2001; 46: 422-5.

Dohrenwend BP. Levav I, Shrout PE et al. Socioeconomic status and psychiatric disorders: the causation-selection issue. Science 1992; 255: $946-52$

Rodgers B, Korten AE, Jorm AE et al. Non-linear relationships in associations of depression and anxiety with alcohol use. Psychological Medicine 2000; 30: 421-32. 